\title{
Identification of Determinants Influencing the Performance of MSMEs
}

\author{
Sapna Surjan, Sandeep Srivastava
}

\begin{abstract}
Industrialization is backbone of developing economy like India, among which major share is of MSMEs. The number of MSMEs is increasing fiercely due to easy start-up policy, but its survival and growth is becoming difficult due to immense competition. In the context of MSME, Performance measurement is still not properly defined. In this paper a conceptual model is proposed for measuring the MSMEs performance. This is a quantitative study, which conducted a survey of 608 MSMEs in Madhya Pradesh. The result of this study shows that all independent variable has a significant correlation to the MSMEs profit along with a moderating effect of Entrepreneur skills. The research is expected to contribute a lot for academics, MSMEs and government to effectively measure MSMEs performance in today's dynamic environment.

Keywords : Micro small and medium enterprises (MSMEs); performance measurement; conceptual framework; cost of credit, electricity.
\end{abstract}

\section{INTRODUCTION}

\section{A. Research background}

The Micro Small and Medium Enterprises (MSME) sector had emerged as a pulsating and dynamic sector in world as well as in India over the last few decades.It contributes significantly in the socio-economic development of the economy by promoting entrepreneurship and generating huge employment opportunities at comparative lower capital cost, next only to agriculture (Annual report of MSME 2017-18). Its contribution is significant as compare to large industries with regards to their share in Indian economy. The MSME sector contributes about 50\% of total manufacturing output and it has major share in exports (Annual report of MSME 2010-11). It contributes 8\% of gross domestic product (GDP) by employing around 73 million people in 31 million undertakings (Annual report of MSME 2012-13).

Indian MSMEs are livelihood source of million but still majorities of enterprises are in unorganized sector.

Revised Manuscript Received on July 22, 2019.

Sapna Surjan,

Research scholar, Jaypee University of Engineering and Technology, Guna, (M. P.), India

Dr Sandeep Srivastava,

Assistant Professor, Jaypee University of Engineering and Technology, Guna, (M. P.), India
This sector has a lot of potential for new entrepreneur and developing enterprises to achieve next level of enterprises. The advancement of MSMEs, therefore, becomes an apex area for policy maker. This MSME sector had Significant share in economic growth and social contribution, which emphasized government to take necessary initiatives for its betterment, so they came up with MSME ACT 2006. Despite of their fruitful contribution in socio-economic contribution in economy still MSMEs face numerous challenges in their growth prospects, financial constraints, obsolete technology, inadequate infrastructure and etc. Das(2008).

Every business large or small needs to measure its Performance to attain its organizational objectivesi.e survival, profit and growth. In large industries performance measurement indicator are well established whereas MSMEs are still lacking behind. MSMEs required the identification of the factors affecting its performance measurement.In this paper a conceptual model is proposed for measuring the MSMEs performance. The factors affect the MSMEs performance proposed are credit institution, cost of credit, working capital requirement, electricity and transportation, labour, raw material, market, competitor, machine \& equipment, training, regulatory taxes \&subsidy and entrepreneur skills.

The outcome of this research is expected to contribute to the MSMEs owners to achieve organizational objectives. In addition, it can also be fruitful to the academic and government (policy maker) to provide an understanding of the factors affecting MSMEs performance.

\section{LITERATURE REVIEW}

\subsection{Factors for measuring MSMEs performance}

MSMEs are considered to be the engine of economic development and employment (Collinson and Houlden, 2005; Ghobadian and Gallear, 1996; Radas and Bozic, 2009). MSMEs sector have many positive characteristics as compare to large firms like innovation, cost and flexibility while these small firms are limited by capital requirement, market share and managerial resources (Motwani et.al, 1999). In spite of its importance in developing 
country like India, these sectors constantly face challenges due to dynamic business environment in India (Gupta and Cawthon 1996). In the present study, the following main problemsare identified through literature review, telephonic interview and personal discussion with the owners and managers of entreprises.

Availability of adequate finance from formal sector is the main constraint faced by the MSMEs from last few decades. (Thornhill,2006; Das , 2008; Guest , 1997; Pasadillia, 2010 ). These firms do not have easy access to credit to meet its working capital requirement due to its collateral requirement and cost i.e fixed cost associated with its supervision, loan appraisal and collection (Radas and Bozic, 2009; Wilson, 1995).A scarcity of public infrastructure services also adversely affect the growth and survival of MSME sector (Das ,2008; Williamson , 2000; Reinikka and Svensson ,2001; Das et al, 2001; Lahiri , 2012 ,Nath and Singh , 2010). Poor and unstable electricity supply has been the major limitation infront of business sector(Adenikinju,2003; Singh, 2012; Venkatesh and Muthiah, 2011). Effective transport infrastructure facilitate industrial development (Kaushik and Kaur, 2011; Ponmani, 2011).

For MSMEs, finding and retaining suitable labour from local market is a key issue as opportunities for career growth are meager as compare to large firms (Gunnigle and Brady, 1984). Labour are more interested in their age -earning s profile rather than current earning as like everyone they also want safe present as well as future(Siebert and Addison, 1991). For the smooth running of industries constant supply of raw material is needed as it is the initial step in manufacturing of product (Parr, 2002). Industries are considered to be the backbone of economy due to its significant contribution in national income (Keeble, 1997; Lange, 2011). Small industries always face shortage of raw material due to its financial constraint, less demand as compare to large firms so they fails to achieve economies of scale in production (Nath and Singh, 2010; Thapa et al., 2008),therefore raw material should be easily available at affordable prices for smooth working of firms (Koch and McGrath, 1996; Spokane, 1991).MSMEs are highly affected by market as compare to large enterprises due to often its limitation in resources and size (Afuah, 2003; Marjanova, 2008; Tidd, 2001). Today's customers demand and expectation are high due to which market became highly competitive (Marjanova, 2008). Market knowledge is very essential element in deciding the success and failure of the business (Trivedi, 2013; Marcati et al., 2010; Kor and Mesko, 2013). Competition is good for economy as it leads to innovation, but excessive competition makes survival of the firms difficult especially in a same locality (Beaudry and Swann, 2001; Burgelman et al., 2004). Excessive competition may lead to struggle for raw material,skilled labour, logistics etc which further increase the cost of production(Hall, 2002; Berry 1998; Baral 2013; De Vos et al., 2009).
Technological factor is an important elementfor competitiveness of any business (Masurel et al., 2010). Competitiveness means how efficiently and effectively resources are used in the process of production; which can be attained via the use of advanced technology (Huselid, 1995). Technology capabilities are very important assets or resources which include technology, product, process, knowledge, experience and organization (Guan and Ma, 2003; Kabongo and Okpara, 2014). India has a good technical ability with a well developed intellectual infrastructure, but still it rank very low in adapting and developing new technologies, especially in MSME sector(Swain and Pratihar, 2002; Cheng et al., 2002; Tunzelmann and Acha, 2005). Training helps in increasing capacity earning as well as job satisfaction among employees. MSMEs lack job training because they have a zenith probability of labour turnover as better trained employee choose for opportunities in large industries where they can get ample of opportunity for career advancement(Arthur and Hendry,1990; Storey, 1999; Barber et al., 1999; Williamson et al., 2002). In the MSMEs, training per employee is noted to be less as compare to large firm as it is less productive for them (Bosworth, 1989). In small firms due to lack of financial resources training and development of employee is a costly affair (Cardon, 2003).Regulatory factors play an important role in the success of business. The globalization increases competition (Mali (1998)). All the policies made by government should have simplified legal and regulatory frameworkas well as good governance(Sudan (2005); Rathod(2007)).

\subsection{Performance measurement of MSMEs}

Business success is about achieving the desired goals and objectives of a firm, which is not explicitly defined (Foley \& Green, (1989); (Ngwangwama, Ungerer, \&Morrison, (2013)). Performance of MSMEs can be measured by financial and non-financial parameters although the financial criteria have been given zenith attention in the literature. The most common performance measure of small business have been financial performance, such as profit, turnover or return on investment ((Barkham et al., 1996; Brüderl and Preisendörfer, 1998; Forsaith and Hall, 2000; Gray, 1998; Ibrahim and Goodwin, 1986; Kalleberg and Leicht, 1991; Kelmar, 1991). Most of the MSMEs measure their performance on the basis of the profit (Kaplan \& Norton, 1992; Atkinson, Waterhouse \& Wells, 1997; Henri, 2004; Halab, Barrett \&Dyt, 2010). Profit measures are effectively used for motivating and controlling the activities of managers and employees ofenterprises (Otley, 2001; Drury, 2004; Otley, 2007).

The nature and complexity of entrepreneurship and its relation to firm performance is continuously research in the field of business performance. (Rauch et al. ,2009; Covin\&Slevin ,1991; Zahra ,1993; Covin\& Lumpkin ,2011). The effect of Entrepreneur Orientation on 
firm performance has been found to be moderated by other variables.(Lechner\&Gudmundsson ,2014 ; Rottenberger ,2013).

\section{FRAMEWORK FOR MEASURING PERFORMANCE OF MSMES}

\subsection{CONCEPTUAL MODEL}

On the basis of literature review, theoretical framework is build in which the performance of MSMEs depend on some internal and external factors. The model of the performance of MSMEs (dependent variable) with the factors that affect the performance of MSMEs (independent variables) along with entrepreneur orientation (moderating variable) is being proposed.

This model is depicted in figure 1 where thirteen independent variables including credit institution, cost of credit, working capital requirement, electricity, transportation, labour, raw material, market, competitor, machine \& equipment, training, regulatory and taxes \&subsidy are studied to know their affects on performance of MSMEs i.e firms profit with a moderating variable entrepreneur orientation.

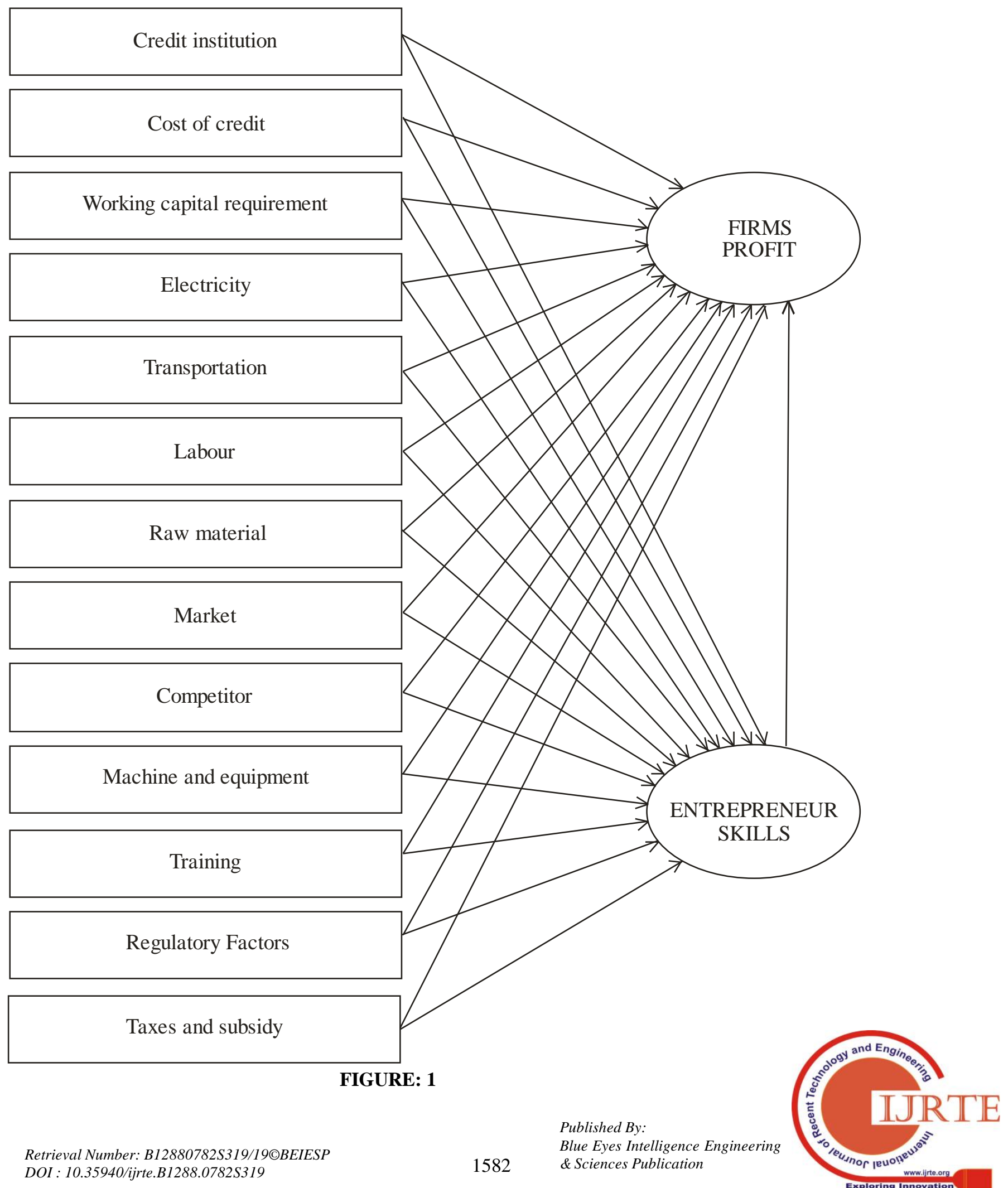




\subsection{HYPOTHESIS}

This study is done with the motive to examine the relationship between the MSMEs profit and its thirteen independent variables along with a moderating variable. After reviewing the literature, the researcher proposes following hypothesis so as to study the impact of these independent variables on the firms profit.

H1a Credit Institution will positively affect the performance of MSMEs.

H1b Credit Institution will positively affectthe Entrepreneur skills.

H2a Cost Of Credit will positively affectthe performance of MSMEs.

$\mathrm{H} 2 \mathrm{~b}$ Cost Of Credit will positively affectthe Entrepreneur skills.

H3a Working Capital Requirement will positively affectthe performance of MSMEs.

H3b Working Capital Requirement will positively affectthe Entrepreneur skills.

H4a Electricity will positively affect the performance of MSMEs.

H4b Electricity will positively affectthe Entrepreneur skills.

H5a Transportation will positively affectthe performanceof MSMEs.

H5b Transportation will positively affectthe Entrepreneur skills.

H6a Labour will positively affectthe performance of MSMEs. H6b Labour will positively affectthe Entrepreneur skills.

H7a Raw Material will positively affectthe performance of MSMEs.

H7b Raw Material will positively affectthe Entrepreneur skills.

H8a Market will positively affectthe performance of MSMEs. H8b Market will positively affectthe Entrepreneur skills.

H9a Competitor will positively affectthe performance of MSMEs.

H9b Competitor will positively affectthe Entrepreneur skills.

H10a Machine \& Equipment will positively affectthe performance of MSMEs.

H10b Machine \& Equipment will positively affectthe Entrepreneur skills.

H11a Training will positively affectthe performance of MSMEs.

H11b Training will positively affectthe Entrepreneur skills.
H12a Regulatory factor will positively affectthe performance of MSMEs.

H12b Regulatory factorwill positively affect the Entrepreneur skills.

H13a Taxes \& Subsidy will positively affectthe performance of MSME.

H13b Taxes \& Subsidy will positively affectthe Entrepreneur skills.

H14 Entrepreneur orientation will positively affectthe performance of MSME.

\section{METHODOLOGY}

It is a quantitative study, which makes use of statistical tools for analyzing the data. In this research conceptual model will be tested so as to check whether it describe the relationship between the performance of MSMEs and the factors affecting its performance along with the moderating variable.

This research is explanatory research as it focused on identifying the factors that measures performance of MSMEs. The method used in gaining data in this study is a questionnaire with a 5-point likert scale. Primary data is collected through random sampling and judgment sampling of 608 MSMES located in Madhya Pradesh, India. The method used credit institution (X1), cost of credit (X2), working capital requirement (X3), electricity (X4), transportation (X5), labour (X6), raw material (X7), market (X8), competitor (X9), machine \& equipment (X10), training (X11), regulatory (X12) and taxes \&subsidy (X13) as dependent variable to measure the performance of MSMEs in terms of firms profit $(\mathrm{Y})$ as independent variable and entrepreneur skills as moderating variable(M).

\section{RESULT}

5.1 Measurement Assessment

In this paper, Construct validity determines the extent to which a scale measures a variable of interest. Thus a principal components factor analysis with varimax rotation was conducted to investigate the distinctions among credit institution, cost of credit, working capital requirement, electricity, transportation, labour, raw material, market, competitor, machine \& equipment, training, regulatory, taxes \&subsidy, entrepreneur orientation and firms profit. In this study, the Kaiser-Meyer-Olkin measure of sampling adequacy (0.872) showed good sampling adequacy. As per the result, the fifteen factors have no cross-construct loading above 0.5 , which is a good indicator of discriminant validity. The research model also indicate convergent validity with factor loadings higher than 0.5 for each construct. Consequently, these results confirm that each of the fifteen constructs is uni-dimensional factoriallydistinct. 
Reliability was evaluated by using the Cronbach alphavalue that check the internal consistency of the independent variables represented in the research model. The reliability value of each variable are as follows: credit institution $=0.918$, cost of credit $=0.909$, working capital requirement $=0.919$, electricity $=0.916$, transportation $=0.912$, labour $==0.912$, raw material $=$ 0.910 , market $=0.921$, competitor $=0.914$, machine $\&$ equipment $=0.912$, training $=0.915$, regulatory $=0.912$, taxes \&subsidy $=0.910$, entrepreneur skills $=0.909$ and firms profit $=0.902$.

Table 1. Rotated Component Matrix ${ }^{\text {a }}$

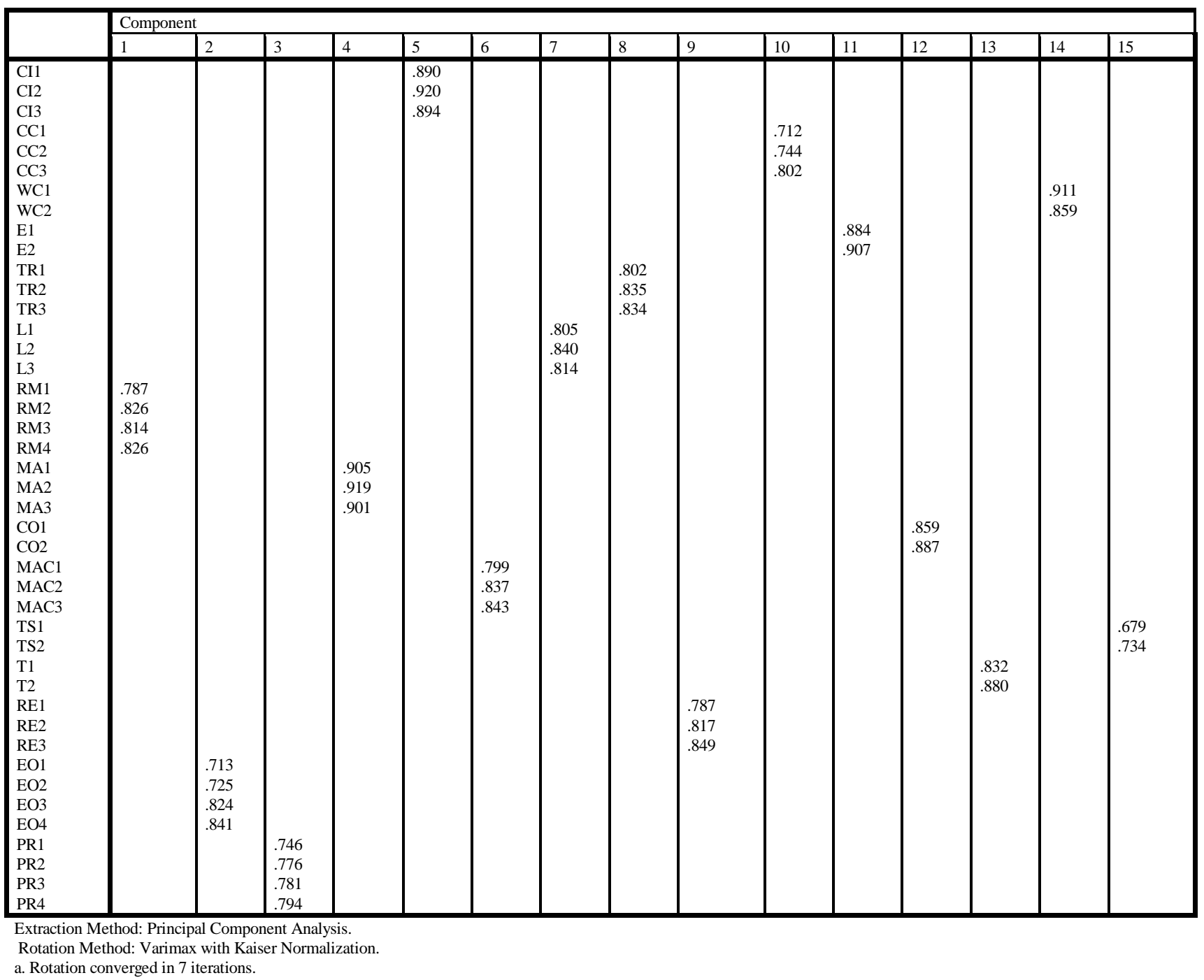

\subsection{Hypothesis Testing}

The hypothesis was tested using the multiple regression analysis of SPSS 9.0 for Windows. The R2 was used to assess the proposed model's overall predictive fit. Properties of causal paths, including the value of standardized path coefficients, t-value and variance explained for each equation in the hypothesized model are presented in fig 2. In hypotheses $\mathrm{H} 1 \mathrm{a}, \mathrm{H} 2 \mathrm{a}, \mathrm{H} 3 \mathrm{a}$, H4a, H5a, H6a, H7a, H8a, H9a, H10a, H11a, H12a,
H13a, H14, we investigate the influence of credit institution, cost of credit, working capital requirement, electricity, transportation, labour, raw material, market, competitor, machine \& equipment, training, regulatory, taxes \&subsidy, entrepreneur orientation on firms profit. As per the result the higher effect on profit was ofmarket (beta value $=0.189, \mathrm{t}$ value $=10.061, \mathrm{p}<0.005$ ) then cost of credit(beta value $=0.169, \quad \mathrm{t} \quad$ value $=6.422$, $\mathrm{p}<0.005)$, followed by taxes 
and $\operatorname{subsidy}($ beta value $=0.162, \mathrm{t}$ value $=5.847, \mathrm{p}<0.005)$, entrepreneur skills $($ beta value $=0.154, \mathrm{t}$ value $=5.851$, $\mathrm{p}<0.005$ ), working capital(beta value $=0.108, \quad \mathrm{t}$ value $=5.697, \mathrm{p}<0.005)$, electricity $($ beta value $=0.102, \mathrm{t}$ value $=4.935, \mathrm{p}<0.005)$, raw material $($ beta value $=0.079$, $\mathrm{t}$ value $=3.239, \mathrm{p}<0.005$ ), transportation $($ beta value $=0.169, \mathrm{t}$ value $=3.192, \mathrm{p}<0.005$ ), labour (beta value $=0.066, \mathrm{t}$ value $=2.824, \quad \mathrm{p}<0.005$ ), and credit institution(beta value $=0.055, \mathrm{t}$ value $=2.810, \mathrm{p}<0.005)$. However machine and equipment's (beta value $=0.054, \mathrm{t}$ value $=2.371$, $\mathrm{p}=0.018$ ), regulatory (beta value $=0.049, \mathrm{t} \quad$ value $=2.12$, $\mathrm{p}=0.034)$, training $($ beta value $=0.038, \mathrm{t}$ value $=1.816$, $\mathrm{p}=0.070$ ) and competitor (beta value $=0.036$, $\mathrm{t}$ value $=1.639, \mathrm{p}=0.102$ ), has no significant effect on profit at the 0.05 level. Therefore hypotheses H1a, H2a, H3a, H4a, H5a, H6a, H7a, H8a, H13a, H14 were supported while hypotheses H9a, H10a, H11a, H12a were rejected. According to the result a significant percentage of variance is explained by the proposed model in terms of firms profit $(\mathrm{R} 2=82.5 \%, \mathrm{~F}$-value $=199.832, \mathrm{p}<0.001)$. The result shows that, market exhibit the strongest direct effect on profit followed by cost of credit, taxes and subsidy, entrepreneur skills, working capital, electricity, raw material, transportation, labour and credit institution.

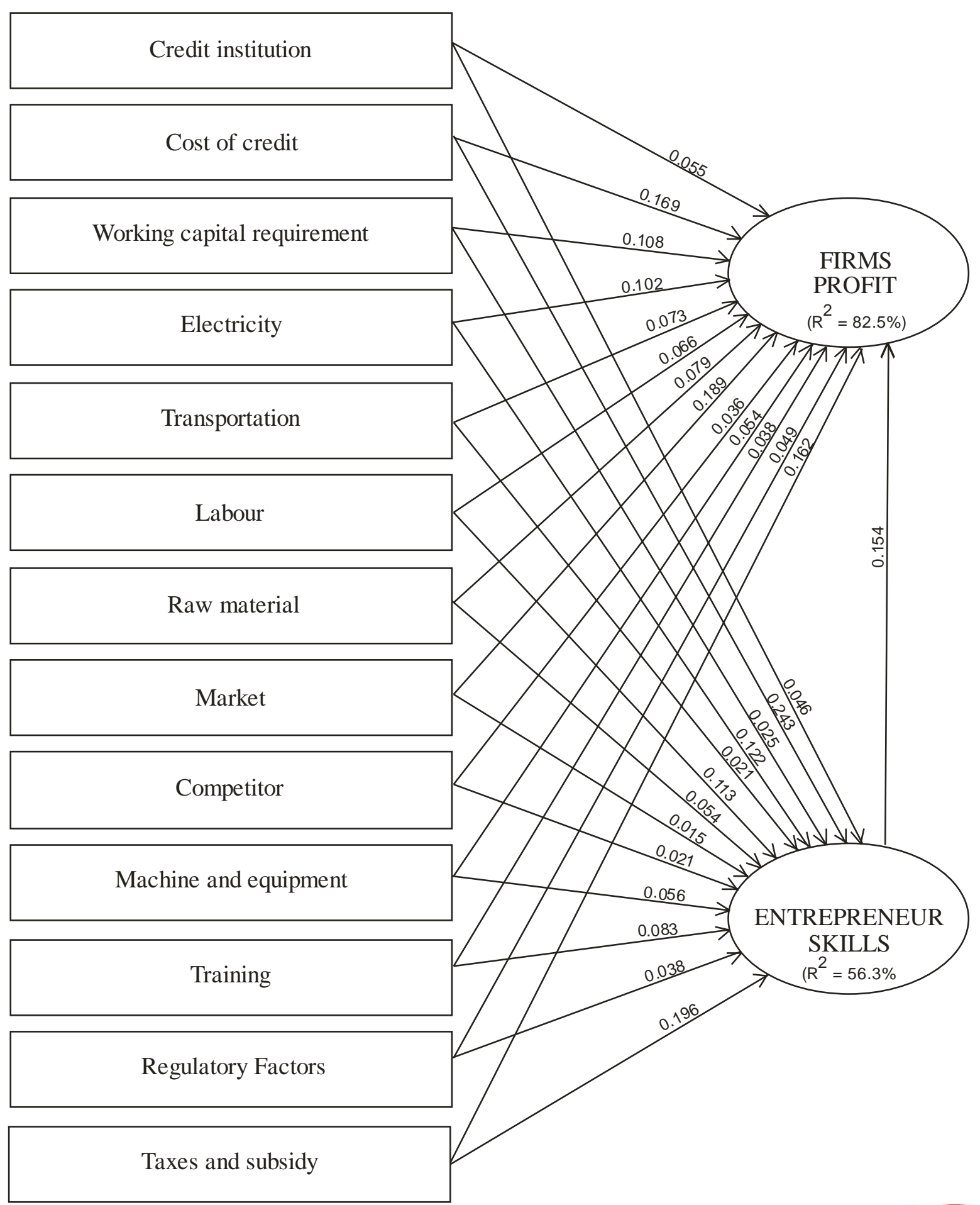

Figure 2. Hypothesis Testing Results $(\mathbf{p}<0.005)$ 
Hypotheses H1b, H2b, H3b, H4b, H5b, H6b, H7b, H8b, $\mathrm{H} 9 \mathrm{~b}, \mathrm{H} 10 \mathrm{~b}, \mathrm{H} 11 \mathrm{~b}, \mathrm{H} 12 \mathrm{~b}, \mathrm{H} 13 \mathrm{~b}$ examine the path from credit institution, cost of credit, working capital requirement, electricity, transportation, labour, raw material, market, competitor, machine \& equipment, training, regulatory, taxes \&subsidy to entrepreneur orientation. We found that cost of credit (beta value $=0.243, \mathrm{t}$ value=6.069, $\mathrm{p}<0.001$ ), taxes and subsidy (beta value $=0.196, \mathrm{t}$ value $=4.616, \mathrm{p}<0.001$ ), electricity (beta value $=0.122, \mathrm{t}$ value $=3.853, \mathrm{p}<0.001$ ) and labour (beta value $=0.113, \mathrm{t}$ value $=3.133, \mathrm{p}=0.002$ ) had $\mathrm{a}$ significant positive effect on the Entrepreneur skills. However credit institution (beta value $=0.046$, $\mathrm{t}$ value $=1.491, \mathrm{p}=0.136$ ), working capital requirement (beta value $=0.025, \mathrm{t} \quad$ value $=0.842, \mathrm{p}=0.400$ ), transportation (beta value $=0.021, \mathrm{t}$ value $=0.585$, $\mathrm{p}=0.559$ ), raw material (beta value $=0.054, \mathrm{t}$ value $=1.404, \mathrm{p}=0.161$ ), market (beta value $=0.015, \mathrm{t}$ value $=0.523, \mathrm{p}=0.601$ ), competitor (beta value $=0.021, \mathrm{t}$ value $=626, p=0.532$ ), machine $\&$ equipment (beta value $=0.056, \mathrm{t}$ value $=1.572, \mathrm{p}=0.116)$, training $($ beta value $=0.083, \mathrm{t}$ value $=2.521, \mathrm{p}=0.021)$, regulatory $($ beta value $=0.038, \mathrm{t}$ value=1.059, $\mathrm{p}=0.290$ ) had no significant influence on entrepreneur skills at the 0.05 level. Thus hypothesis $\mathrm{H} 2 \mathrm{~b} \mathrm{H} 4 \mathrm{~b} \mathrm{H} 6 \mathrm{~b} \mathrm{H} 13 \mathrm{~b}$ was supported, while hypotheses H1b, H3b, H5b, H7b, H8b, H9b, H10b, H11b, $\mathrm{H} 12 \mathrm{~b}$ was rejected. About 56.3 percent of the variance in entrepreneur orientation was accounted by cost of credit, electricity, labour and taxes and subsidy. The total effect of cost of credit was 0.543 $(=0.169+2.43 * 0.154), \quad$ electricity was 0.121 $(=0.102+0.122 * 0.154), \quad$ labour was 0.083 $(=0.066+0.113 * 0.154)$ and taxes and subsidy was 0.079 $(=0.049+0.196 * 0.154)$ on profit.

\section{DISCUSSION}

In this paper an attempt is made to empirically validate a conceptual framework for measuring the MSMEs performance.This study investigated the direct effects of credit institution, cost of credit, working capital requirement, electricity, transportation, labour, raw material, market, competitor, machine \& equipment, training, regulatory, taxes \&subsidy on firms profit and examine the indirect effect of credit institution, cost of credit, working capital requirement, electricity, transportation, labour, raw material, market, competitor, machine \& equipment, training, regulatory, taxes \&subsidy on firms profit with the indirect effect through Entrepreneur skills. Combining these perspectives and then empirically examining the determinants that are responsible for the firms profit for improving our knowledge of various variable and their relation to MSME success. The result suggest that credit institution, cost of credit, working capital requirement, electricity, transportation, labour, raw material, market, taxes \&subsidy, entrepreneur skills are all variables that determine the firms profit, with market making an apex influence than cost of credit, followed by taxes and subsidy, entrepreneur skills, working capital, electricity, raw material,transportation, labour and credit institution. While cost of credit, electricity, labour and taxes and subsidy were each making direct influence on firm'sprofit, while they were also indirectly related to firms profit through entrepreneur skills. This result suggests that entrepreneur skills play a crucial intervening role in the relationship of cost of credit, electricity, labour and taxes and subsidy to firms profit.

This finding also provides several implications for measuring success of MSME in terms of firms profit. Whileentrepreneur skills has the strong influence on firms profit. As suggested by our proposed model, firms profit will increase if these factors like market, cost of credit, taxes and subsidy, entrepreneur skills, working capital, electricity, raw material, transportation, labour and credit institution were appropriately managed. While machine and equipment's, regulatory factors, training and competitor had not positive influence on MSMEs profit in the state of Madhya Pradesh. Thefinding suggests that entrepreneur skills have great impact on the firms profit. If entrepreneur analysis the business environment accurately to grab the hidden opportunity then the chances of business success increases. The finding suggests that cost of credit, taxes and subsidy, electricity and labour had a significant positive effect on the Entrepreneur skills.

The result of this study encourage the MSMEs owners to pay more attention on market, cost of credit, taxes\&subsidy, entrepreneur skills, working capital, electricity, raw material, transportation, labour and credit institution to increase the firms profit. The present study has tried to predict firms profit-related measures with good reliability and validity which can be used by MSMEs owners engaged in manufacturing and service sector to intensify their understanding of measuring business performance and its factors and so as to enhance the chance of success in enterprises.

\section{CONCLUSION}

The research is aneffort for determining the factors responsible for influencing the performance of MSMEs. The model was proposed using firm's profit as a theoretical framework. To know the influences of credit institution, cost of credit, working capital requirement, electricity, transportation, labour, raw material, market, competitor, machine \& equipment, training, regulatory, taxes \&subsidy and entrepreneur skills on (performance of MSME) firms profit. The outcome of this study to performance of MSMEs research is twofold. Initial, it has observed the direct relationship of the determinant on the firms profit. Later, it has observed the indirect relationship of the determinant on the firms profit through entrepreneur skills. It also suggested that an entrepreneur skill plays a crucial role in the relationship of cost of credit, electricity, labour and taxes and subsidy 
value to firms profit. The outcomes of this study have implications for MSMEs in order to survive and improve its growth. Considering the huge invested in MSME sector and it is of paramount importance to any economy in terms of GDP, employment and production, so it is of great importance to academic and government (policy maker) for understanding important factors affecting MSMEs performance.

However, this research has several limitations that can be addressed in the future research. First, investigation of performance of MSMEs is measured with the one quantitative factor i.e. firms profit while there are many more quantitative factors like turnover, sales etc. as well as many more qualitative factors. The discussed findings and their implications are obtained from both manufacturing and service sector of MSMEs that examined only in state of Madhya Pradesh of India. It is imperative to validate our proposed performance of MSMEs in terms of firms profit model with different states of India and world.Secondly, the size of sample i.e 608 enterprises was used, which is another limitation. A confirmatory analysis and cross-cultural validation using a large sample gathered elsewhere is required for greater generalization of the proposed model. Third, while the value of R2is relatively high for proposed model but still there can be other variable that can affectfirm's profit accurately. Lastly, this study is conducted in a single state of a country like India. Additional research efforts are needed to evaluate the validity of the investigated models and our findings by conducting it in different states of India as well as in a whole economy. More Longitudinal evidence can increase our knowledge regarding cause and effect relationship between or among variables important to firms profit in measuring the MSMEs performance of different countries.

\section{REFERENCES}

1. Adenikinju, A.F. (2003) "Electric infrastructure failures in Nigeria: a survey-based analysis of the costs and adjustment responses", Energy Policy, Vol. 31, No. 14, pp.1519-1530.

2. Afuah, A. (2003) "Innovation Management: Strategies, Implementation, and Profits", Oxford University Press, New York, USA.

3. Alkali, M. (2012) "An empirical study of entrepreneurs educational level and the performance of small business manufacturing enterprises in Bauchi State, Nigeria", Interdisciplinary Journal of Contemporary Research in Business, Vol. 4, No. 6, pp.914-923.

Analoui, F. and Karami, A. (2002) 'CEOS and development of meaningful mission statement', Corporate Governance: The International Journal of Business in Society, Vol. 2, No. 3, pp.13-30.

4. Anderson, W. (2011) 'Internationalization opportunities and challenges for small and medium-sized enterprises from developing countries', Journal of African Business, Vol. 12 , No. 2, pp.198-217.

5. Annual report of MSME 2017-18, Ministry of Micro Small and Medium Enterprises, Government of India.

6. Annual report of MSME 2010-11, Ministry of Micro Small and Medium Enterprises, Government of India.

7. Annual report of MSME 2012-13, Ministry of Micro Small and Medium Enterprises, Government of India.

8. Arthur, M.B. and Hendry, C. (1990) 'Human resource management and the emergent strategy of small to medium sized business units', International Journal of Human Resource Management, Vol. 1, No. 3, pp.233-250. 9. Atkinson, A. A., Waterhouse, J. H., \& Wells, R. B. (1997). "A stakeholder approach to strategic performance measurement", MIT Sloan Management Review, 38(3), 25-38.

10. Banks, M.C., Bures, A.L. and Champion, D.L. (1987) 'Decision making factors in small business: training and development', Journal of Small Business Management, Vol. 25, No. 1, pp.19-25.

11. Baral, S.K. (2013) 'An empirical study on changing face of MSME towards emerging economies in India', Journal of Radix International Educational and Research Consortium, Vol. 2, No. 1, pp.1-21.

12. Barber, A.E., Wesson, M.J., Roberson, Q.M. and Taylor, M.S. (1999) 'A tale of two job markets: organizational size and its effects on hiring practices and job search behaviour', Personnel Psychology, Vol. 52, No. 4, pp.841-867.

13. Beaudry, C. and Swann, P. (2001) Growth in Industrial Clusters: A Bird's Eye View of the United Kingdom, Stanford Institute for Economic Policy Research, Discussion Paper No. 00-38.

14. Berry, M. (1998) 'Strategic planning in small high tech companies', Long Range Planning, Vol. 31, No. 3, pp.455-466. Si-

15. Bosworth, D. (1989) 'Barriers to growth: the labour market', in Barber, J., Metcalfe, J.S. and Porteous, M. (Eds.): Barriersto Growth in Small Firms, Vol. 9, pp.105-120, Routledge, London.

16. Burgelman, R., Maidique, M.A. and Weelwright, S.C. (2004) Strategic Management of Technology and Innovation, McGraw, New York.

17. Cardon, M.S. (2003) 'Contingent labor as an enabler of entrepreneurial growth', Human Resource Management Journal, Vol. 42, No. 4, pp.357-373.

18. Cant, M. and Brink, A. (2003) 'Problems experienced by small businesses in South Africa', 16th Annual Conference of Small Enterprise Association of Australia and New Zealand Cooper, R.G. (1994) 'New products: the factors that drive success', International Marketing Review, Vol. 11, No. 1, pp.60-76.

19. Cheng, C.H., Hsiao, L.Y.C. and Tasi, C.J. (2002) 'High-tech industry in Taiwan: support for high-tech ventures', Asia Pacific Tech Monitor, Vol. 1, No. 1, pp. $1-35$.

20. Chowdhury, S.A., Azam, K.G. and Islam, S. (2013) 'Problems and prospects of SME financing in Bangladesh', Asian Business Review, Vol. 2, No. 4, pp.51-58.

21. Collinson, S. and Houlden, J. (2005), "Decision-Making and Market Orientation in the Internationalization Process of Small and Medium-Sized Enterprises", MIR: Management International Review, 45(4): 413-436.

22. Cortes, M. (1987) Success in Small and Medium Scale Enterprises: The Evidence from Colombia, Oxford University Press, Oxford, New York.

23. Covin, J. G., \& Lumpkin, G. T. (2011). Entrepreneurial orientation theory and research: Reflections on a needed construct. Entrepreneurship: Theory and Practice, 35(5), 855-872. http://doi.org/10.1111/j.1540-6520.2011.00482.x

24. Covin, J. G., \&Slevin, D. P. (1991). A Conceptual Model of Entrepreneurship as Firm Behavior. Entrepreneurship: Theory \& Practice, 16(1), 7-25. http://doi.org/1042- 2587-91-161

25. (2008) 'ERIA Research Project Report 2007-5'. SMEs in India: issues and possibilities in times of globalization [online], 69-97. $\quad$ available r from <http://www.eria.org/SMEs\%20in\%20India_Issues\%20and\%20Possibil ities\%20in\%20Times\%2 0of\%20Globalisation.pdf> [18 October 2014]

26. Das, K., Morris, S., Basant, R., Ramachandran, K. and Koshy, A. (2001) The Growth and Transformation of Small Firms in India, Oxford University Press, New Delhi.

27. De Vos, A., Dewettinck, K. and Buyens, D. (2009) 'The professional career on the right track, a study on the interaction between career self-management organizational management in explaining employee outcomes, 
European Journal of Work and Organizational Psychology, Vol. 18, No. 1, pp.55-80.

28. Foley, P., \& H. Green (Eds.). (1989). Small business success. London: Chapman.

29. Forsaith, D. and Hall, J. (2000) Financial Performance and the Size of a Business: Proceedings of 45th ICSB World Conference 'Entrepreneurial SME's - Engines for Growth in the Millennium'. Brisbane: International Counci for Small Business. [CD-ROM]

30. FridahMuriungiMwobobia (2012) - The Challenges Facing Small-Scale Women Entrepreneurs: A Case of Kenyall, International journal of business administration, Vol 3 , issue 2, PP 112-121

31. Ghobadian, A. and Gallear, D.N.(1996), "Total quality management in SMEs", Omega Int. J. MgmtSci, 24(1): 83-106.

32. Gisha.P.Mathai (2015) -Challenges and Issues in Micro, Small and Medium Enterprises (MSMEs) in India: A Current Scenario of Economic Growthl, Vol 4, Issue 7, PP 162-163

33. Gray, J. H. (1998) 'Self-employment as a Career Option for Redundant Workers', Faculty of Business \& Economics Working Paper 51/98. Victoria: Monash University

34. Guan, J. and Ma, N. (2003) 'Innovative capability and export performance of Chinese firms', Technovation, Vol. 23, No. 9, pp.737-747.

35. Guest, D.E. (1997) 'Human resource management and performance: a review and research agenda', International Journal of Human Resource Management, Vol. 8, No. 3, pp.263-276.

36. Gunnigle, P. and Brady, T. (1984) 'The management and industrial relations in the small firms', Employee Relations, Vol. 6, No. 5, pp.21-24.

37. Gupta, M. and Cawthon, G.(1996), "Managerial implication of flexible manufacturing for small/medium-sized enterprises",Technovation journal, Vol 16, Issue 2, PP 77-94

38. Halabi, A. K., Barrett, R., \&Dyt, R. (2010). Understanding financial information used to assess small firm performance: An Australian qualitative study. Qualitative Research in Accounting \& Management, 7(2) 163-179. http://dx.doi.org/10.1108/11766091011050840

39. Hall, D.T. (2002) Careers In and Out of Organizations, Vol. 36, pp.105-121, Sage Publications, Thousand Oaks.

40. Henri, J. (2004). Performance measurement and organizational effectiveness: Bridging the gap", Managerial Finance, 30(6) 93-123. http://dx.doi.org/10.1108/03074350410769137

41. Huselid, M.A. (1995) 'The impact of human resource management practices on turnover, productivity, and corporate financial performance', Academy of Management Journal, Vol. 38, No. 3, pp.635-670

42. Ibrahim, A. B. and Goodwin, J. R. (1986) 'Perceived Causes of Success in Small Business', American Journal of Small Business 12(1): 41-50.

43. IshuGarg\&SurajWalia (2012) -Micro, Small \& Medium Enterprises (Msmes) in Post Reform India: Status \& Performancell, Vol 1, No 3, PP 134-141.

44. Jahnshahi, A., Nawaser, K., Paghaleh, M.J., Mohammad, S and Khaksar, S. (2011) 'The role of government policy and the growth of entrepreneurship in the micro, small (\&) medium-sized enterprises in India: an overview', Australian Journal of Basic and Applied Sciences, Vol. 5, No. 3, pp.1563-1571

45. Kabongo, J.D. and Okpara, J.O. (2014) 'ICT possession among Congolese SMEs: an exploratory study', Journal of Small Business and Enterprise Development, Vol. 21, No. 2, pp.313-326.

46. Kalleberg, A. L. and Leicht, K. T. (1991) 'Gender and Organizational Performance: Determinants of Business Survival and Success', Academy of Management Journal 34(1): $136-61$.

47. Kalra, S.C. (2009) SMEs in India: The Challenges Ahead [online] http://articles.economictimes. indiatimes.com/2009-02-03/news/28468202 1 _indian-sme-sector-smesegment-sme-units (accessed May 2016).

48. Kaman, V., McCarthy, A.M., Gulbro, R.D. and Tucker, M.L. (2001) 'Bureaucratic and high commitment human resource practices in small service firms', Human Resource Planning, Vol. 24, No. 1, pp.33-44.

49. Kaplan, R. S., \& Norton, D. P. (1992). The Balanced Scorecard - Measures that Drive Performance The
Balanced Scorecard - Measures. Harvard business review, 70(1), 71-79.

50. Kaushik, S.P. and Kaur, J. (2001) 'Evaluation of industrial politics and infrastructure facilities in National Capital Sub-region, Haryana', Indian Journal of Geography and Environment, Vol. 12, No. 1, pp.31-39.

51. Keeble, D. (1997) 'Small firms, innovation and regional development in Britain in 1990's', Regional Studies, Vol. 31, No. 3, pp.281-293.

52. Kelmar, J. (1991) 'Measurement of Success and Failure in Small Business: A Two Factor Approach', Curtin Business School Working Paper. Perth: Curtin University.

53. Kim, L. (1988) 'Entrepreneurship and innovation in a rapidly developing country', Journal of Development Planning, Vol. 8, No. 1, pp.183-194.

54. Koch, M.J. and McGrath, R.G. (1996) 'Improving labor productivity: human resource management policies do matter', Strategic Management Journal, Vol. 17, No. 5, pp.335-354.

55. Kor, Y. and Mesko, A. (2013) 'Dynamic managerial capabilities: configuration and orchestration of top executive's capabilities and the firm's dominant logic', Strategic Management Journal, Vol. 34, No. 2, pp.233-244.

56. Koufopoulos, D., Logoudis, I. and Pastra, A. (2005) 'Planning practices in the Greek ocean shipping industry', European Business Review, Vol. 17, No. 2, pp.151-176.s.'Krishnaswamy, T.S. (2009) MSME Financing: How to Make it Easy for an Entrepreneur?, State Bank of India, Corporate Centre, Mumbai.ssp:

57. Kristiansen, S. (2003) 'Small-scale Business in rural java: involution or innovation?',Journal of Entrepreneurship, Vol. 12, No.1, pp.21-41

58. Lahiri, R. (2012) 'Problems and prospects of micro, small and medium enterprises (MSMEs) in India in the era of globalization', International Conference at Royal Thimphu College, Bhutan.

59. Lange, P. (2011) Africa - Internet, Broadband and Digital Media $\quad$ Statistics 69 [online] https://www.budde.com.au/Research/Africa-Internet-Broadband-and-D gitalMedia-Statistics- tables-only.html (accessed March 2016).

60. Lechner, C., \&Gudmundsson, S. V. (2014). Entrepreneurial orientation, firm strategy and small firm performance. International Small Business Journal, 32(1), 36-60. http://doi.org/10.1177/0266242612455034.

61. Lee, S.K. and Lee, S.H. (2010) 'The activation of technology finance through support for small and medium-sized enterprises in Korea', International Journal of Business and Management, Vol. 5, No. 4, pp.75-79.

62. Leppard, J. and McDonald, M. (1987) 'A re-appraisal of the role of marketing planning', Journal of Marketing Management, Vol. 3, No. 2, pp.159-71

63. MacGregor, R. and Varazalic, L. (2005) 'A basic model of electronic commerce adoption barriers, a study of regional small businesses in Sweden and Australia', Journal of Small Business and Enterprise Development, Vol. 12, No. 4, pp.510-527

64. Malmberg, A., Malmberg, B. and Lundequist, P. (2000) 'Agglomeration and firm performance: economies of scale, localization and urbanization among Swedish export firms', Environment and Planning A, Vol. 32, No. 2, pp.305-321

65. Mambula, C. (2002) 'Perceptions of SME growth constraints in Nigeria', Journal of Small Business Management, Vol. 40, No. 1, pp.58-65.

66. Man, T.W.Y., Lau, T. and Snape, E. (2008) 'Entrepreneurial competencies and the performance of small and medium enterprises: an investigation through a framework of competitiveness', Journal of Small Business and Entrepreneurship, Vol. 21, No. 3, pp.257-276.

67. Mali, D. D. (1998), "Development of micro, small and medium Enterprises of India: Current Scenario and Challenges', SEDME Vol. 25, No. 4, December.

68. Marcati, A., Guido, G. and Peluso, A.M. (2010) 'What is marketing for SME enterpreneurs? The need to market the marketing approach', Journal of Marketing Trends, Vol. 1, No. 2, pp.67-74.

69. Marjanova, T.J. (2008) "Marketing knowledge and strategy for SMEs: can they live without it?',SAM 
Advanced Management Journal, Vol. 43, No. 2, p.24.

70. Masurel, E., Montfort, K. and Lentink, R. (2010) 'Innovation and diffusion in small firms: theory and evidence', Small Business Economics, Vol.6, No. 4, pp. $327-34$

71. MishuTripathi, Mr. SaurabhTripathi, Mr. RikinDedhia (2016) -Challenges faced by Micro, Small and Medium Enterprise (Msme) Sector In Indiall, International Journal of Science technology and management, Vol 5, Issue 3, PP

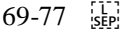

72. Motwani, J.G., Jiang, J.J. and Kumar, A. (1998) 'A comparative analysis of manufacturing practices of small vs. large West Michigan organizations', Industria Management and Data Systems, Vol. 98, No. 1, pp.8-11.

73. Motwani, J., Dandridge, T., Jiang, J., Soderquist, K. 1999. Managing innovation in French small and medium-sized enterprises. Journal of Small Business Management 37/2, 106-114

74. Mukund Chandra Mehta (2013) -Challenges and Opportunities in Micro, Small and Medium Enterprises in Indiall, 2nd International Conference on Management, Humanity and Economics (ICMHE'2013) May 6-7, 2013 Kuala Lumpur (Malaysia), PP 134-136

75. Narkhede, B.E., Nehete, R.S., Raut, R.D. and Mahajan, S.K. (2014) 'Impact of entrepreneurial skills on the firm's performance: evidence from manufacturing SMEs in India', International Journal of Indian Culture and Business Management (IJICBM), Vol. 8, No. 2, pp.216-236.

76. N. Aruna (2015) -Problems Faced By Micro, Small and Medium Enterprises - A Special Reference to Small Entrepreneurs in Visakhapatnaml, IOSR Journal of business and management, Vol 14, issue 4, PP 43-49

77. Nath, R. and Singh, G. (2010) Creating Competitive SMEs [online] http:www.cii.in/webcams/upload/creating\%competing\%20SMEs.pdf (accessed May 2016).

78. NeeruGarg (2014) -Micro, Small and Medium Enterprises in India: Current Scenario and Challengesll, Paripex Indian Journal of Research, Vol 3, Issue 9, PP 11-13

79. Ngwangwama, M.M., Ungerer, M., \& Morrison, J. (2013). An exploratory study of key success factors for business success of companies in the Namibian tertiary industry. International Journal of Innovations in Business, 2(6), 604-629.

80. Nunnally, J.C., Psychometric Theory, 2nded., McGraw-Hill, NY, 1978.

81. Oakey, R. (1991) 'Innovation and the management of marketing in high technology small firms', Journal of Marketing Management, Vol.7, No. 4, pp.343-356.

82. Ojala, M., Vilpola, I. and Kouri, I. (2006) 'Risks and risk management in ERP project - cases in SME context', Business Information Systems, Vol. 13, No. 1 , pp.134-139.

83. Okreglicka, M. (2014) 'Adoption and use of ICT as a factor of development of small and medium-sized enterprises in Poland', PrzedsiebiorczosciZarzadzanie, T. 15, z. 7, cz. 1, pp.393-405.

84. Olawale, F. and Garwe, D. (2010) 'Obstacles to the growth of new SMEs in South Africa: a principal component analysis approach', African Journal of Business Management, Vol. 4, No. 5, pp.729-738.

85. Oluleye, F.A. and Oyetayo, O. (2010) 'Raw materials development and utilisation in Nigeria: promoting effective linkage between $\mathrm{R} \& \mathrm{D}$ and SMEs for economic growth and development', Journal of Management and Corporate Governance, Vol. 2, No. 1, pp.41-54.

86. Otley, D. (2001). Accounting performance measurement: A review of its purposes and practices", International Journal of Business Performance Management, 3(2-4), 245-260. http://dx.doi.org/10.1504/IJBPM.2001.000102

87. Otley, D. (2007). Accounting performance measurement: a review of its purposes and practices. In Neely A. (Ed), Business Performance Measurement: Unifying theory and integrating practice (2nd ed),

88. Parr, J.B. (2002) 'Agglomeration economies: ambiguities and confusion', Environment and Planning A, Vol. 34 No. 4, pp.717-731.

89. Pasadilla, G.O. (2010) Financial Crisis, Trade Finance, and SMEs: Case of Central Asia, Asian Development Bank Institute, Japan.
90. Ponmani, R. (2011) 'Infrastructure and SMEs development in selected Asian countries', Asian Journal of Research in Social Science and Humanities, Vol. 1, No. 4, pp.465-473.

91. Radas, S. and Bozic, L. (2009), "The antecedents of SME innovativeness in an emerging transition economy", Technovation, 29: 438-450.

92. Rathod, C. B. (2007). Contribution of Indian small scale entrepreneurs to economic growth in India: Opportunities and challenges in global economy. Prabandh- Journal of Management and Research, 23, 1-12. SEF?

93. Rauch, A., Wiklund, J., Lumpkin, G. T., \&Frese, M. (2009). Entrepreneurial Orientation and Business Performance: An Assessment of Past Research and Suggestions for the Future. Entrepreneurship: Theory \& Practice, 33(3), 761-787. http://doi.org/10.1111/j.1540-6520.2009.00308.

94. Rogers, E.M. (1995) Diffusion of Innovations, 4th ed., Free Press, New York.

95. Rogers, E.M. (2003) Diffusion of Innovations, Free Press, New York, NY.

96. Romano, C. and Ratnatunga, J. (1995) 'The role of marketing: its impact on small enterprise research', European Journal of Marketing, Vol. 29, No. 7, pp.9-30.

97. Reinikka, R. and Svensson, J. (2001) 'Confronting competition: investment, profit and risk', Uganda Recovery: The Role of Farms, Firms, and Government, Kampala.

98. SangitaG.Patil\&P.T.Chaudhari (2014) -Problems of Small Scale Industries in Indiall, International Journal of Engineering and Management Research, vol 4, Issue 2, PP 19-21.

99. Seshasayee, R. (2012) 'Financing SMEs: An Industry Perspective'. www.businessworld.in[online] 09 March 2012. available from<http://www.businessworld.in/news/more/advertisingfeatures/financing-smes-an-industry-perspective/391725/page-1.html> [18 October 2014]

100. Siebert, S.W. and Addison, J. (1991) 'Internal labour markets: causes and consequences', Oxford Review of Economic Policy, Vol. 7, No. 1, pp.76-92.

101. Singh, B., Mathews, J., Mullineux, G. and Medland, T. (2009) 'Product development in manufacturing SMEs: current state, challenges and relevant supportive techniques', International Conference on Engineering Design, Stanford University, Stanford, CA, USA

102. Singh, B. (2012) 'Identifying critical barriers in the growth of Indian micro, small and medium enterprises (MSMEs)', International Journal of Business, Competition and Growth, Vol. 2, No. 1, pp.84-105.

103. Siti Sarah bt. Omar, Lawrence Arokiasamy\&Maimunah Ismail (2009) - The Background and Challenges Faced by the Small Medium Enterprises. A Human Resource Development Perspectivell, International Journal of business and management, vol 4 , issue 10 , PP 95-102.

104. Spokane, A.R. (1991) 'Career intervention', Education and Training, Vol. 39, No. 1, pp.219-224.

105. Storey, D.J. (1999) 'Human resource management policies and practices in SMEs in the UK: Does it really influence their performance?',Centre for Small and Medium-sized Enterprises, Vol. 3, pp.137-165, Warwick Business School, University of Warwick.

106. Sudan, F. K. (2005). Challenges in Micro and Small Scale Enterprise Development: Some Policy Issues. Synergy: I.T.S. Journal of IT and Management, 3(2), 67-81.

107. Subrahmanya, M.H.B. (2005) 'Small-scale industries in India in the globalization era: performance and prospects', International Journal of Management and Enterprise Development, Vol. 2, No.1, pp.122-139.

108. Swain, A. and Pratihar, S. (2002) 'Innovations and challenges in MSME sector', DRIEMS Business Review, Vol. 1, No. 1, pp.81-85

109. Thapa, A., Thulaseedharan, A., Goswami, A. and Joshi, L.P. (2008) 'Determinants of street entrepreneurial success', The Journal of Nepalese Business Studies, Vol. 5, No. 1, pp.85-92.

110. Thornhill, S. (2006) 'Knowledge, innovation and firm performance in high- and low technology regimes', J. Bus. Venturing, Vol. 21, No. 5, pp.687-703. 
111. Tidd, J. (2001) 'Innovation management in context: environment, organization and performance', Int. J. Manag. Rev., Vol. 3, No. 3, pp.169-183 [online] http://dx.doi.org/10.1111/1468- 2370.00062 (accessed March 2016).

112. Todd, P.R. and Javalgi, R.G. (2007) 'Internationalization of SMEs in India', International Journal of Emerging Markets, Vol. 2, No. 2, pp.166-180.

113. Toftoy, C.N. and Chatterjee, J. (2004) 'Mission statements and the small business', Business Strategy Review, Vol. 15, No. 3, pp.41-44.

114. Trivedi, J.Y. (2013) 'A study on marketing strategies of small and medium sized enterprises', Research Journal of Management Sciences, Vol. 2, No. 8, pp.245-259.

115. Troilo, M.L. (2014) 'Collaboration, product innovation, and sales: an empirical study of Chinese firms', Journal of Technology Management in China, Vol. 9, No. 1, pp.37-55.

116. Tunzelmann, N.V. and Acha, V. (2005) 'Innovation in low-tech industries', Business and Management, Innovation, Business Policy and Strategy, pp.407-432, The Oxford Handbook of Innovation, Oxford.

117. Ughetto, E. (2008) 'Does internal finance matter for R\&D? New evidence from a panel of Italian firms', Cambridge Journal of Economics, Vol. 32, No. 6, pp.907-925.

118. Venkatesh, S. and Muthiah, K. (2011) 'Power fluctuations -usage of servo voltage stabilizers in industries', International Journal of Applied Engineering Research, Vol 2, No. 1, pp.283-289, Dindigul.

119. Wennekers, A.R.M. and Thurik, A.R. (1999) 'Linking entrepreneurship and economic growth', Small Business Economics, Vol. 13, No. 1, pp.27-55.

120. Wheelen, T. and Hunger, D. (2008) Strategic Management and Business Policy, Vol. 8, pp.56-77, Addison-Wesley Publishing Company, Massachusetts.

121. Wickham, P.A. (1997) 'Developing a mission for entrepreneurial venture', Management Decision, Vol. 35 , No. 5, pp.373-381.

122. Wiklund, J. and Shepherd, D. (2003) 'Knowledge-based resources, entrepreneurial orientation, and the performance of small and medium-sized businesses', Strategic Management Journal, Vol. 24, No. 12, pp.1307-1314.

123. Williamson, I.O. (2000) 'Employer legitimacy and recruitment success in small businesses', Entrepreneurship Theory and Practice, Vol. 7, No. 8, pp.27-42.

124. Williamson, I.O., Cable, D.M. and Aldrich, H.E. (2002) 'Smaller but not necessarily weaker: how small businesses can overcome barriers to recruitment', Managing People in Entrepreneurial Organizations (Advances in Entrepreneurship, Firm Emergence and Growth, Vol. 5), pp.83-106, Emerald Group Publishing Limited, Bingley, UK.

125. Wilson, L. (1995) 'Occupational standards for small firms', Executive Development, Vol. 8, No. 6, pp.18-20.

126. Zahra, S. (1993). A Conceptual Model Of Entrepreneurship As Firm Behaviour: A Critique And Extension. Entrepreneurship Theory and Practise, 17(18), 5-20. 